\title{
Molecular analysis of mitochondrial gene mutations in Korean patients with nonsyndromic hearing loss
}

\author{
JAE WOONG BAE ${ }^{1 *}, \mathrm{KYU}_{\text {YUP LEE }}{ }^{*}$, SOO YOUNG CHOI ${ }^{1}$, \\ SANG HEUN LEE ${ }^{2}$, HONG-JOON PARK ${ }^{3}$ and UN-KYUNG KIM ${ }^{1}$
}

${ }^{1}$ Department of Biology, College of Natural Sciences, Kyungpook National University, Daegu; ${ }^{2}$ Department of Otolaryngology, College of Medicine, Kyungpook National University, Daegu; ${ }^{3}$ Soree Ear Clinic, Seoul, Korea

Received February 20, 2008; Accepted March 28, 2008

DOI: 10.3892/ijmm_00000005

\begin{abstract}
Mutations in mitochondrial DNA (mtDNA) are a major cause of hearing loss. In this study, we performed a systematic mutational screening of the $12 \mathrm{~S}$ rRNA, tRNA ${ }^{\text {Ser(UCN), }}$ tRNA $^{\text {Lys }}$ and tRNA ${ }^{\text {Leu(UUR) }}$ genes in 227 unrelated patients with nonsyndromic hearing impairment for the first time in a Korean population. We found two individuals with an A1555G mutation, which is a frequency $(0.9 \%)$ lower than that of other East Asians. Furthermore, two novel variants (C895T and 961-CC insertion) in the 12S rRNA gene were identified in the affected individuals, but were absent in 217 controls, indicating that they may play a role in the pathogenesis of hearing loss. Notably, 961delT and T1005C mutations were identified at similar frequencies in both patients and control subjects. Our data suggest that these variants seem to be polymorphisms rather than causes of disease. On the other hand, we did not find any of the known deafness-associated mutations in these tRNA genes. These data suggest that the $12 \mathrm{~S}$ rRNA gene may be a hot spot for mitochondrial mutations causing hearing loss in the Korean population.
\end{abstract}

\section{Introduction}

Congenital hearing loss is one of the most common sensory disorders in humans, affecting 1 in 1,000 newborns, and genetic causes are thought to be responsible for over $50 \%$ of cases in developed countries $(1,2)$. Of the hearing loss disorders attributable to genetic causes, approximately $70 \%$ are classified

Correspondence to: Dr Un-Kyung Kim, Department of Biology, College of National Sciences, Kyungpook National University, Daegu 702-701, Korea

E-mail:kimuk@knu.ac.kr

Dr Hong-Joon Park, Soree Ear Clinic, Seoul, Korea

E-mail: hjparkmd@hanmail.net

${ }^{*}$ Contributed equally

Key words: hearing loss, mitochondrial DNA, 12S rRNA, mutation, Korean as nonsydnromic since hearing impairment is the only symptom, while $30 \%$ are classified as syndromic and are associated with other clinical features.

Mutations in mitochondrial DNA (mtDNA) have been associated with both syndromic and nonsyndromic deafness (3-5). In particular, the mitochondrial genes encoding $12 \mathrm{~S}$ ribosomal RNA (rRNA) (MTRNR1) and the transfer RNA $(\text { tRNA })^{\operatorname{Ser}(\mathrm{UCN})}$ gene have been found to be associated with nonsyndromic hearing loss. Different mutations in the $12 \mathrm{~S}$ rRNA gene, the A1555G, A827G, T1095C, C1494T, and 961 mutations, can cause maternally inherited, nonsyndromic hearing loss, which in most cases is induced or aggravated by ototoxic aminoglycosides (6-15). Among these mutations, the A1555G mutation seems to be the most common cause of aminoglycoside-induced hearing loss, especially in those cases with family history $(8,16)$. It has also been demonstrated to cause hearing loss even without an aminoglycoside injection, and consequently may be related to inner ear susceptibility. Therefore, it may be that the mutation manifests itself as a diminished ability to repair cochlear damage from a variety of causes, including, for example, noise and aging $(8,17,18)$.

Furthermore, five nonsyndromic deafness-associated mutations, A7445G, G7444A, 7472insC, T7510C, and T7511C, have been identified in the tRNA ${ }^{\text {Ser(UCN) }}$ gene (19-29). These mutations often occur in homoplasmy or in high levels of heteroplasmy, indicating a high threshold for pathogenicity. It is believed that mutations in this gene can cause a failure in tRNA metabolism, thereby leading to a decrease in the amount of affected tRNAs, which subsequently results in insufficient mitochondrial protein synthesis and respiration defects (30). However, nonsyndromic deafness-associated mtDNA mutations, such as the A1555G or A7445G mutations, are often insufficient to produce clinical deafness, since some individuals carrying these mutations have normal hearing $(6,8,18,19,31)$. Thus, other factors including other mtDNA mutations, nuclear background, and environmental factors modulate the phenotypic variability and penetrance of deafness associated with these mtDNA mutations. In addition, A3243G, T3171C in the tRNA ${ }^{\mathrm{Leu}(\mathrm{UUR})}$ gene and G8363A in the tRNA ${ }^{\text {Lys }}$ gene are also known to be associated with maternally inherited syndromic hearing loss $(4,32,33)$.

However, less is known about the incidence of the deafness-associated mtDNA mutations in the Korean population. 
With the aim of identifying mtDNA mutations associated with hearing loss, we undertook a systematic and extended mutation screening of mitochondrial genes including the $12 \mathrm{~S}$ rRNA, tRNA $^{\text {Ser(UCN) }}$, tRNA ${ }^{\text {Lys }}$ and tRNA ${ }^{\text {Leu(UUR) }}$ genes in 227 unrelated Korean patients with nonsyndromic hearing impairment. To examine the role of the GJB2 and GJB6 genes in the phenotypic expression of the known or putative deafness-associated mtDNA mutation, we also performed mutation screening of the GJB2 gene and PCR assay for the 342-kb deletion of the GJB6 gene.

\section{Materials and methods}

Subjects. A total of 227 nonsyndromic hearing loss patients were recruited from the Soree Ear Clinic, Seoul, Korea and a local school for deafness. There were 107 male and 120 female patients, with an age range of 7 months to 65 years (mean age, 13.7 years). In the case of patients who attended the Soree Ear Clinic, audiological studies were carried out including pure tone audiometry, tympanometry, or auditory brainstem response test (ABR) in a sound-treated room. Pure-tone average (PTA) was calculated as an average of the threshold measured at $0.5,1.0,2.0$ and $3.0 \mathrm{KHz}$ for comparing subgroups of patients. One hundred and fiftyseven patients from the Soree Ear Clinic were chosen for this study. All of the patients had severe hearing loss over $95 \mathrm{~dB}$ of PTA or over $90 \mathrm{~dB}$ in ABR. The medical records of deaf individuals in the school were reviewed, and 70 patients with profound hearing loss above $95 \mathrm{~dB}$ were chosen for the study. None of the subjects showed unilateral hearing loss, past history of meningitis, head trauma, noise trauma, infectious disease associated with hearing loss, or other acquired hearing loss. Two control groups were employed: i) 75 Korean subjects who had no hearing loss and were evaluated with pure tone audiometry (group 1), and ii) 142 normal healthy Korean controls who were not examined by audiometric evaluation (group 2).

All participants provided written informed consent according to the protocol approved by the Ethics Committee of Kyungpook National University Hospital prior to the study.

Mutational analyses of the mitochondrial $12 S$ rRNA, $t R N A^{\operatorname{Ser}(U C N)}, t R N A^{\text {Lys }}$ and $t R N A^{\operatorname{Leu}(U U R)}$ genes. Genomic DNA was extracted from peripheral blood using a FlexiGene DNA extraction kit (Qiagen, Hilden, Germany) or from buccal swab specimens using Puregene Buccal Cell Core Kit A (Qiagen).

The mitochondrial $12 \mathrm{~S}$ rRNA, tRNA ${ }^{\mathrm{Ser}(\mathrm{UCN})}, \mathrm{tRNA}^{\mathrm{Lys}}$ and tRNA ${ }^{\text {Leu(UUR) }}$ genes were amplified by polymerase chain reaction (PCR) using the appropriate intronic primer sets. PCR was performed in a total of $25 \mu 1$ reaction, containing $0.2 \mathrm{mM}$ of each deoxynucleotide, $15 \mathrm{pmol}$ of each forward and reverse primer, $1.0-1.5 \mathrm{mM} \mathrm{MgCl}_{2}, 10 \mathrm{mM}$ Tris- $\mathrm{HCl}$ ( $\mathrm{pH} 8.3$ ), $50 \mathrm{mM} \mathrm{KCl}, 0.75 \mathrm{U}$ of Taq DNA polymerase (Solgent, Korea), and 25 ng of genomic DNA. PCR conditions were as follows: 35 cycles of denaturation at $95^{\circ} \mathrm{C}$ for $30 \mathrm{sec}$; annealing at $55^{\circ} \mathrm{C}$ or $57^{\circ} \mathrm{C}$, depending on the primers for $30 \mathrm{sec}$; and extension at $72^{\circ} \mathrm{C}$ for $1 \mathrm{~min}$. The first denaturation step and the last extension step were at $95^{\circ} \mathrm{C}$ for $2 \mathrm{~min}$ and $72^{\circ} \mathrm{C}$ for $10 \mathrm{~min}$, respectively. Five microliters of the PCR products were separated and visualized on a $2 \%$ agarose gel. Fifteen microliters of this PCR product were then treated with $0.3 \mathrm{U}$ of shrimp alkaline phosphatase (USB) and $3 \mathrm{U}$ of exonuclease I (USB) at $37^{\circ} \mathrm{C}$ for $1 \mathrm{~h}$, followed by incubation at $80^{\circ} \mathrm{C}$ for $15 \mathrm{~min}$. This was diluted with an equal volume of $\mathrm{dH}_{2} \mathrm{O}$, and $6 \mu \mathrm{l}$ was used for the final sequencing reaction. Sequencing reactions were performed in both directions on the PCR products in reactions containing $5 \mathrm{pmol}$ of primer, $0.25 \mu 1$ of ABI Big Dye Terminator v3.1 Cycle Sequencing Kit, and $1 \mu \mathrm{l}$ of $5 \mathrm{X}$ dilution buffer (400 mM Tris-HCl, pH 9.0, and $10 \mathrm{mM} \mathrm{MgCl}_{2}$ ). Cycling conditions were $95^{\circ} \mathrm{C}$ for $2 \mathrm{~min}$ followed by 35 cycles of $94^{\circ} \mathrm{C}$ for $20 \mathrm{sec}, 55^{\circ} \mathrm{C}$ for $20 \mathrm{sec}$, and $60^{\circ} \mathrm{C}$ for $4 \mathrm{~min}$. Sequencing reaction products were ethanol precipitated, and the pellets were resuspended in $10 \mu \mathrm{l}$ of formamide loading dye. An ABI 3130XL DNA sequencer was used to resolve the products, and data were analyzed by using ABI Sequencing Analysis (v.5.0) and LasergeneSeqMan software. The resultant sequences were compared with the updated Cambridge sequence (GenBank Accession No. NC_001807) (34).

The samples were also tested for the presence of mutations in the coding region of $G J B 2$ by direct sequencing and the $342-\mathrm{kb}$ deletion of the GJB6 gene by a specific PCR assay as previously reported by del Castillo et al (35).

Secondary structure prediction. Structures for the wild-type and mutated mitochondrial $12 \mathrm{~S}$ rRNAs were generated using the RNAfold software from the Vienna RNA package (36). RNAfold predicts RNA secondary structure based on minimum energy requirements and pair probabilities.

\section{Results}

Mitochondrial 12S rRNA and tRNA gene analyses. Mutational screening of the entire mitochondrial 12S rRNA gene in 227 subjects with nonsyndromic hearing loss and 217 hearing individuals revealed the presence of 29 nucleotide deviations from the Cambridge sequence as shown in Table I (34). Of these changes, three were novel and 26 had been previously described. The A1555G mutation, which is the most common cause of hearing loss linked to mutations in mitochondrial DNA, was found in two patients, and in one of these it was present in heteroplasmy. Both of the patients had familial history, and showed profound hearing loss in audiological evaluation. This result indicates a frequency of about $0.9 \%$ for the $\mathrm{A} 1555 \mathrm{G}$ mutation in this group. One novel variant, C895T in the 12S rRNA gene, was present in homoplasmy in one patient and this substitution was not observed in controls (Fig. 1A). This variant was further evaluated by phylogenetic analysis of this mtDNA variant and mtDNAs from other organisms. As shown in Table I, the C895 is highly conserved in humans, mouse, bovine, and Xenopus laevis (34,37-39). Since the A $1555 \mathrm{G}$ mutation was predicted to alter the secondary structure of the $12 \mathrm{~S}$ rRNA molecule which affects both transcriptional fidelity and interaction of the ribosome with aminoglycoside antibiotics, a prediction of the secondary structure of the $12 \mathrm{~S}$ rRNA molecule was carried out to study the possible functional effect of this novel change (36). In this model, the C895T change resulted in a structural change compared to the wild-type prediction (Fig. 1B). 
Table I. Variants in the mitochondrial 12s rRNA gene in Korean subjects with nonsyndromic hearing loss. ${ }^{\mathrm{a}}$

\begin{tabular}{|c|c|c|c|c|c|c|}
\hline \multirow[t]{2}{*}{ Position } & \multirow[t]{2}{*}{ Replacement } & \multicolumn{3}{|c|}{ Frequency } & \multirow{2}{*}{$\begin{array}{l}\text { Conservation } \\
(\mathrm{H} / \mathrm{B} / \mathrm{M} / \mathrm{X})^{\mathrm{e}}\end{array}$} & \multirow{2}{*}{$\begin{array}{l}\text { Previously } \\
\text { reported }^{\mathrm{f}}\end{array}$} \\
\hline & & In patients ${ }^{\mathrm{b}}$ & In normal subjects ${ }^{c}$ & In normal subjects ${ }^{\mathrm{d}}$ & & \\
\hline 709 & $\mathrm{G}$ to $\mathrm{A}$ & $48 / 227$ & $16 / 75$ & $28 / 142$ & G/A/A/- & Yes \\
\hline 750 & A to $\mathrm{G}$ & $227 / 227$ & $75 / 75$ & $142 / 142$ & $\mathrm{~A} / \mathrm{A} / \mathrm{A} /-$ & Yes \\
\hline 752 & $\mathrm{C}$ to $\mathrm{T}$ & $5 / 227$ & $3 / 75$ & $2 / 142$ & $\mathrm{C} / \mathrm{C} / \mathrm{A} /-$ & Yes \\
\hline 769 & $\mathrm{G}$ to $\mathrm{A}$ & $1 / 227$ & $0 / 75$ & $0 / 142$ & G/A/T/- & Yes \\
\hline 789 & $\mathrm{~T}$ to $\mathrm{C}$ & $0 / 227$ & $1 / 75$ & $0 / 142$ & $\mathrm{~T} / \mathrm{T} / \mathrm{T} / \mathrm{A}$ & Yes \\
\hline 827 & A to $\mathrm{G}$ & $4 / 227$ & $4 / 75$ & $2 / 142$ & $\mathrm{~A} / \mathrm{A} / \mathrm{A} / \mathrm{A}$ & Yes \\
\hline 869 & $\mathrm{C}$ to $\mathrm{T}$ & $1 / 227$ & $0 / 75$ & $0 / 142$ & C/T/T/A & Yes \\
\hline 895 & $\mathrm{C}$ to $\mathrm{T}$ & $1 / 227$ & $0 / 75$ & $0 / 142$ & $\mathrm{C} / \mathrm{C} / \mathrm{C} / \mathrm{C}$ & No \\
\hline 904 & $\mathrm{C}$ to $\mathrm{T}$ & $1 / 227$ & $0 / 75$ & $0 / 142$ & $\mathrm{C} / \mathrm{C} / \mathrm{C} / \mathrm{T}$ & Yes \\
\hline 958 & $\mathrm{C}$ to $\mathrm{T}$ & $1 / 227$ & $0 / 75$ & $0 / 142$ & $\mathrm{C} / \mathrm{C} / \mathrm{A} / \mathrm{T}$ & Yes \\
\hline 961 & $\mathrm{C}$ ins & $2 / 227$ & $0 / 75$ & $1 / 142$ & $\mathrm{~T} / \mathrm{T} / \mathrm{A} / \mathrm{A}$ & Yes \\
\hline 961 & $\mathrm{CC}$ ins & $1 / 227$ & $0 / 75$ & $0 / 142$ & $\mathbf{T} / \mathbf{T} / \mathbf{A} / \mathbf{A}$ & No \\
\hline 961 & $\mathrm{~T}$ del $+\mathrm{Cn}$ & $9 / 227$ & $3 / 75$ & $10 / 142$ & $\mathrm{~T} / \mathrm{T} / \mathrm{A} / \mathrm{A}$ & Yes \\
\hline 1005 & $\mathrm{~T}$ to $\mathrm{C}$ & $3 / 227$ & $1 / 75$ & $2 / 142$ & $\mathrm{~T} / \mathrm{T} / \mathrm{T} / \mathrm{T}$ & Yes \\
\hline 1009 & $\mathrm{C}$ to $\mathrm{T}$ & $1 / 227$ & $0 / 75$ & $0 / 142$ & $\mathrm{C} / \mathrm{T} / \mathrm{C} / \mathrm{T}$ & Yes \\
\hline 1041 & A to $\mathrm{G}$ & $3 / 227$ & $3 / 75$ & $3 / 142$ & $\mathrm{~A} / \mathrm{A} / \mathrm{T} / \mathrm{T}$ & Yes \\
\hline 1048 & $\mathrm{C}$ to $\mathrm{T}$ & $10 / 227$ & $2 / 75$ & $7 / 142$ & $\mathrm{C} / \mathrm{C} / \mathrm{T} / \mathrm{C}$ & Yes \\
\hline 1095 & $\mathrm{~T}$ to $\mathrm{C}$ & 0/227 & $0 / 75$ & $1 / 142$ & $\mathrm{~T} / \mathrm{T} / \mathrm{T} / \mathrm{T}$ & Yes \\
\hline 1107 & $\mathrm{~T}$ to $\mathrm{C}$ & $19 / 227$ & $5 / 75$ & $8 / 142$ & $\mathrm{~T} / \mathrm{C} / \mathrm{T} / \mathrm{T}$ & Yes \\
\hline 1116 & A to $\mathrm{G}$ & $1 / 227$ & $0 / 75$ & $0 / 142$ & $\mathrm{~A} / \mathrm{A} / \mathrm{A} / \mathrm{T}$ & Yes \\
\hline 1118 & A to $\mathrm{T}$ & $1 / 227$ & $1 / 75$ & $0 / 142$ & $\mathrm{~A} / \mathrm{A} / \mathrm{A} / \mathrm{C}$ & No \\
\hline 1119 & $\mathrm{~T}$ to $\mathrm{C}$ & $10 / 227$ & $2 / 75$ & $2 / 142$ & $\mathrm{~T} / \mathrm{T} / \mathrm{T} / \mathrm{G}$ & Yes \\
\hline 1310 & $\mathrm{C}$ to $\mathrm{T}$ & $1 / 227$ & $0 / 75$ & $1 / 142$ & $\mathrm{C} / \mathrm{G} / \mathrm{C} / \mathrm{T}$ & Yes \\
\hline 1382 & A to $\mathrm{C}$ & $7 / 227$ & $5 / 75$ & $7 / 142$ & $\mathrm{~A} / \mathrm{A} / \mathrm{A} / \mathrm{G}$ & Yes \\
\hline 1391 & $\mathrm{~T}$ to $\mathrm{C}$ & $0 / 227$ & $1 / 75$ & $0 / 142$ & $\mathrm{~T} / \mathrm{A} / \mathrm{T} / \mathrm{A}$ & Yes \\
\hline 1438 & A to $\mathrm{G}$ & $224 / 227$ & $70 / 75$ & $139 / 142$ & $\mathrm{~A} / \mathrm{A} / \mathrm{A} / \mathrm{G}$ & Yes \\
\hline 1442 & $\mathrm{G}$ to $\mathrm{A}$ & $1 / 227$ & $0 / 75$ & $1 / 142$ & $\mathrm{G} / \mathrm{A} / \mathrm{A} / \mathrm{C}$ & Yes \\
\hline 1555 & A to $\mathbf{G}$ & $2 / 227$ & $0 / 75$ & $0 / 142$ & $\mathbf{A} / \mathbf{A} / \mathbf{A} / \mathbf{A}$ & Yes \\
\hline 1598 & $\mathrm{G}$ to $\mathrm{A}$ & $9 / 227$ & $2 / 75$ & $2 / 142$ & $\mathrm{G} / \mathrm{A} / \mathrm{T} / \mathrm{T}$ & Yes \\
\hline
\end{tabular}

${ }^{a}$ Known and putative pathogenic mutations are indicated in boldface. ${ }^{b}$ Number of patients with the substitution/total patients analyzed. ${ }^{\mathrm{c} N u m b e r}$ of controls with the variant/total controls with audiological evaluation. ${ }^{\mathrm{d}}$ Number of controls with the variant/total controls without audiological evaluation. ${ }^{e}$ Conservation of nucleotide for the $12 \mathrm{~S}$ rRNA gene in humans (H), bovine (B), mouse (M), and Xenopus laevis (X). ${ }^{f}$ See the online mitochondrial genome database Mitomap (http://www.mitomap.org), mtDB-Human Mitochondrial Genome Database (http://www.genput.uu.se/mtDB/) or Human Mitochondrial Genome Polymorphism Database (http://mtsnp.tmig.or.jp/mtsnp).

Notably, three different variants at position 961 including two known variants, 961-C insertion, delT961Cn, and one novel variant, 961-CC insertion were identified in this study and all of them were present in homoplasmy. As shown in Table I, the delT961Cn mutation was detected in $9 / 227$ patients $(3.9 \%)$. This mutation was also found in $3 / 75(4 \%)$ of control group 1 and 10/142 (7\%) of control group 2. The 961-C insertion was detected in two patients and found in one individual in control group 2. In contrast, the 961-CC insertion was detected in one of the patients, but was not identified in either of the control groups. In addition, the $\mathrm{T} 1005 \mathrm{C}$ variant was first identified in three Chinese patients and suggested to be a pathogenic mutation (40). This variant was also detected in three patients as well as in $1 / 75(0.1 \%)$ of control group 1 and in 2/142 (4.3\%) of control group 2 . Sequencing analyses of the tRNA genes were performed and no mutation associated with hearing loss was identified in those genes in this study.

Mutational analyses of GJB2 and 342-kb deletion of GJB6 genes. Several studies have shown that modifiers encoded by nuclear genes are one of the major modulators of the phenotypic expression of the deafness-associated 12S rRNA gene mutations $(22,41,42)$. To examine the phenotypic heterogeneity observed in the known or putative mtDNA mutations, we performed mutation screening of the GJB2 gene and PCR assay for the $342-\mathrm{kb}$ deletion of the GJB6 gene. Sequencing analysis revealed no mutations in the GJB2 gene in subjects 
$\mathbf{A}$

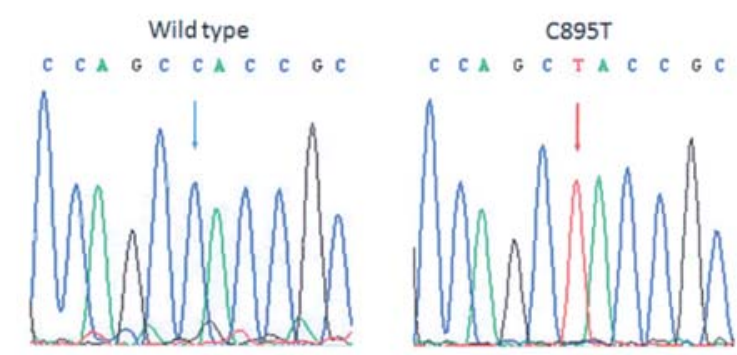

$\mathbf{B}$
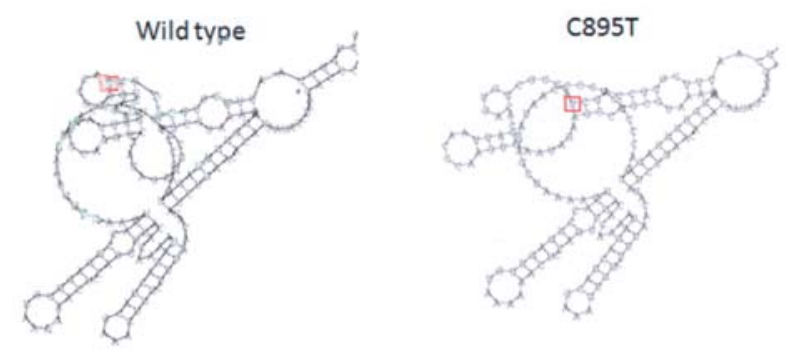

Figure 1. (A) Sequence chromatograms showing the novel C895T variation detected in the mitochondrial $12 \mathrm{~S}$ rRNA gene. (B) The predicted secondary structures of the C895T variant compared to the wild-type prediction.

carrying the A1555G and 961-CC insertion in the 12S rRNA gene. Of nine subjects carrying the delT961Cn mutation, the homozygous $235 \mathrm{delC}$ mutation in the GJB2 gene was found in one patient with profound hearing loss, whereas the other eight subjects with mild or profound hearing loss lacked the mutation in the same gene (data not shown). In addition, one of the subjects showing the 961-C insertion was homozygous for the 235 delC mutation, but another subject with the same mutation did not have any mutation in the GJB2 gene. Both of these patients showed congenital profound hearing loss in audiological evaluation. In addition, one patient with the C895T mutation was heterozygous for the $235 \mathrm{delC}$ mutation in the gene. The GJB6 gene was not detected in any subject in this study.

\section{Discussion}

Mutations in mtDNA are a major cause of hearing loss and most of the molecular defects responsible for mitochondrial disorder-associated hearing loss are mutations in the $12 \mathrm{~S}$ rRNA and tRNA genes $(3,8)$. In the present study, we performed a mutation screening of $12 \mathrm{~S}$ rRNA and tRNA genes in 227 Korean subjects with nonsyndromic hearing loss to examine the prevalence and characterization of mtDNA mutation causing hearing loss in the Korean population. As a result, we identified 29 nucleotide changes including three novel variants in the $12 \mathrm{~S}$ rRNA gene. Of these, the A1555G mutation was found in two patients, accounting for $0.9 \%$ of the study group. Since this mutation was first described in a large Arab-Israeli pedigree, the relevance of the A1555G mutation has been investigated in different hearing-impaired populations $(6-8,18,43,44)$. This mutation was found in $0.6 \%$ of a Caucasian pediatric population, and in $2.4 \%$ in Danish, $1.8 \%$ in Turkish, less than $2.4 \%$ in German, Polish, and Hungarian, and $17 \%$ in Spanish populations (45-48). In Asian nonsyndromic hearing-impaired populations, the incidence of the $\mathrm{A} 1555 \mathrm{G}$ mutation appears to be higher than that in Caucasians: $2.9 \%$ in Chinese, $3 \%$ in Japanese, and $5.3 \%$ in Indonesian populations $(40,49,50)$. In Korea, Jeong et al (51) evaluated the frequency of the A1555G mutation by restriction fragment length polymorphism (RFLP) from 129 unrelated sensorineural hearing loss (SNHL) patients and it was found in $2.3 \%(3 / 129)$ of the group (51). Combined with the results of that study, our data indicate that the A $1555 \mathrm{G}$ mutation occurs in approximately $1.4 \%$ of the Korean population. The prevalence of the A1555G mutation in Koreans seems to be lower than in other East Asians. This difference would result from different genetic backgrounds among Asians.

The C895T change was identified in homoplasmy in one case, and it was not found in any of the controls. Moreover, evaluation of this position in different species showed that the $\mathrm{C}$ at nucleotide 895 was conserved throughout evolution. In addition, the prediction using RNAfold software showed changes in the secondary structure of the $12 \mathrm{~S}$ rRNA in this case. Moreover, this patient was a heterozygote for the $235 \mathrm{delC}$ mutation in the GJB2 gene. Several studies have indicated that the A1555G mutation may be a predisposing mutation, which requires the combined action of environmental factors and/or nuclear modifying genes to cause hearing impairment $(42,52-55)$. To fully understand the pathogenic mechanisms of this mtDNA variant, it would be necessary to perform functional studies of cell lines derived from this patient, but from the data presented here it seems clear that C895T is a mtDNA disease-causing mutation.

The 961delT mutation was more frequently found than other mutations in this study. The 961delT mutation was first reported in one out of 35 patients with a history of aminoglycoside exposure. Since then, several mutations at position 961 such as 961-C insertion, T961G, and T961C mutations have been found in isolated individuals and genetically unrelated families with aminoglycoside-induced and/or nonsyndromic SNHL $(15,28,45,56,57)$. Recently, Kobayashi et al (58) demonstrated that a similar frequency of the 961delT mutation was found in control subjects, and that the hearing loss phenotype did not segregate with this mutation in families. In our study, the $961 \mathrm{delT}$ variant was the most frequent one in the patients, but it was also found in both control groups. In particular, subjects with this variant in group 1 showed a normal hearing level below $20 \mathrm{~dB}$ in both ears. This is consistent with the finding of the abovementioned study that the 961delT mutation was not the cause of hearing loss (58). In addition, the $\mathrm{C}$ insertion(s) at the position 961 were detected in the patient group, but one of these variants (961-C insertion) was also detected in control group 2. $\mathrm{T} 1005 \mathrm{C}$ was present in homoplasmy in five cases and in three normal subjects. Yao et al (61) reported that these variants, 961-C insertion and $\mathrm{T} 1005 \mathrm{C}$, were in the list of characteristic mutations of haplogroup B51b and haplogroup F2 (59-61). Since the haplogroup data were based on phylogenetic information from the populations, these variants may be rare polymorphisms rather than mutations. However, it still remains 
possible that the changes at position 961 are associated with disease as the subject showing the 961-CC insertion variant had a family history showing progressive hearing loss, and the change was not found in any of the controls tested. Therefore, further investigation such as functional analysis is necessary in order to define this variant as pathogenic, and a careful assessment will be needed to determine whether these changes in the vicinity of nucleotide 961 cause hearing loss.

Mitochondrial tRNA genes are a hot spot for mutations in maternally inherited SNHL, as a number of deafness-associated mutations have been identified in three of the 22 tRNA genes including tRNA ${ }^{\text {Ser(UCN) }}$, tRNA ${ }^{\text {Lys }}$, and tRNA ${ }^{\text {Leu(UUR) }}$. In this study, we failed to detect the presence of mutation in these genes. This suggests that mutations in these mitochondrial tRNA genes are not a common cause of deafness in the Korean population.

Usually, a single mutation in the mitochondrial $12 \mathrm{~S}$ rRNA gene or tRNA genes is not sufficient to cause hearing loss, but requires the contribution of other modulating factors such as nuclear modifier gene(s), environment factor(s), or mitochondrial haplotypes for the phenotypic expression. Among the nuclear genes responsible for SNHL, mutations in the GJB2 gene have been of particular interest because they have been found to account for about $50 \%$ of inherited nonsyndromic deafness cases (62). Also, the 342-kb deletion disrupting the GJB6 gene (delGJB6-D13S1830) is common in patients from Spain, France, Germany, the United Kingdom and Brazil, and in patients of Ashkenazi Jewish origin (35,63-65). We studied the potential relationship between mtDNA mutations and mutations in the GJB2 or GJB6 genes for phenotypic expression. A possible interaction was only found in the subject carrying the C895T mutation with heterozygous $235 \mathrm{delC}$ mutation. Since the prevalence of mutations in the GJB2 gene responsible for SNHL was only about $10 \%$ in the Korean population, the GJB2 gene does not seem to be a major modifier gene affecting the severity of hearing loss in this population.

In summary, we observed the frequency of the A1555G mutation to be $1.4 \%$ in the Korean nonsyndromic hearing loss population, and we found the novel C895T and 961-CC insertion variants of the $12 \mathrm{~S}$ rRNA gene that may be associated with SNHL. These data suggest that the $12 \mathrm{~S}$ rRNA gene is the mitochondrial hot spot for mutations causing hearing loss. Further studies are necessary to determine whether there are other genes which also account for a significant proportion of hearing loss in the Korean population.

\section{Acknowledgements}

We thank all the subjects who participated in the present study. We also thank Young-Jun Choi and Jung Ree Lee for recruiting patients and family members. This work was supported by the grant no. RTI04-01-01 from the Regional Technology Innovation Program of the Ministry of Commerce, Industry and Energy (MOCIE) and was supported by the Korea Science and Engineering Foundation (KOSEF) grant funded by the Korean government (MOST) (No. R01-2008-00010431-0). This work was supported by the Ministry of Science and Technology (MoST)/Korea Science and Engineering Foundation (KOSEF) through the Vestibulocochlear Research
Center (VCRC) at Wonkwang University (R13-2002-05500000-0).

\section{References}

1. Petit C, Levilliers J and Hardelin JP: Molecular genetics of hearing loss. Annu Rev Genet 35: 589-646, 2001.

2. Morton NE: Genetic epidemiology of hearing impairment. Ann NY Acad Sci 630: 16-31, 1991.

3. Fischel-Ghodsian N: Mitochondrial deafness mutations reviewed. Hum Mutat 13: 261-270, 1999.

4. Van Camp G and Smith RJ: Maternally inherited hearing impairment. Clin Genet 57: 409-414, 2000.

5. Kokotas H, Petersen MB and Willems PJ: Mitochondrial deafness. Clin Genet 71: 379-391, 2007.

6. Matthijs G, Claes S, Longo-Mbenza B and Cassiman JJ: Nonsyndromic deafness associated with a mutation and a polymorphism in the mitochondrial $12 \mathrm{~S}$ ribosomal RNA gene in a large Zairean pedigree. Eur J Hum Genet 4: 46-51, 1996.

7. Pandya A, Xia X, Radnaabazar J, et al: Mutation in the mitochondrial $12 \mathrm{~S}$ rRNA gene in two families from Mongolia with matrilineal aminoglycoside ototoxicity. J Med Genet 34: 169-172, 1997.

8. Prezant TR, Agapian JV, Bohlman MC, et al: Mitochondrial ribosomal RNA mutation associated with both antibiotic-induced and non-syndromic deafness. Nat Genet 4: 289-294, 1993.

9. Xing G, Chen Z, Wei Q, et al: Mitochondrial 12 S rRNA A827G mutation is involved in the genetic susceptibility to aminoglycoside ototoxicity. Biochem Biophys Res Commun 346: 1131-1135, 2006.

10. Xing G, Chen Z, Wei Q, et al: Maternally inherited nonsyndromic hearing loss associated with mitochondrial $12 \mathrm{~S}$ rRNA A827G mutation in a Chinese family. Biochem Biophys Res Commun 344: 1253-1257, 2006.

11. Zhao L, Young WY, Li R, Wang Q, Qian Y and Guan MX: Clinical evaluation and sequence analysis of the complete mitochondrial genome of three Chinese patients with hearing impairment associated with the 12S rRNA T1095C mutation. Biochem Biophys Res Commun 325: 1503-1508, 2004.

12. Tessa A, Giannotti A, Tieri L, Vilarinho L, Marotta G and Santorelli FM: Maternally inherited deafness associated with a T1095C mutation in the mDNA. Eur J Hum Genet 9: 147-149, 2001.

13. Wang Q, Li R, Zhao H, et al: Clinical and molecular characterization of a Chinese patient with auditory neuropathy associated with mitochondrial 12S rRNA T1095C mutation. Am J Med Genet 133: 27-30, 2005.

14. Zhao H, Li R, Wang Q, et al: Maternally inherited aminoglycoside-induced and nonsyndromic deafness is associated with the novel C1494T mutation in the mitochondrial 12S rRNA gene in a large Chinese family. Am J Hum Genet 74: 139-152, 2004.

15. Li R, Xing G, Yan M, et al: Cosegregation of C-insertion at position 961 with the A1555G mutation of the mitochondrial $12 \mathrm{~S}$ rRNA gene in a large Chinese family with maternally inherited hearing loss. Am J Med Genet 124: 113-117, 2004.

16. Fischel-Ghodsian N: Genetic factors in aminoglycoside toxicity. Pharmacogenomics 6: 27-36, 2005.

17. Usami S, Abe S, Kasai M, et al: Genetic and clinical features of sensorineural hearing loss associated with the 1555 mitochondrial mutation. Laryngoscope 107: 483-490, 1997.

18. Estivill X, Govea N, Barcelo E, et al: Familial progressive sensorineural deafness is mainly due to the mtDNA A1555G mutation and is enhanced by treatment of aminoglycosides. Am J Hum Genet 62: 27-35, 1998 .

19. Fischel-Ghodsian N, Prezant TR, Fournier P, Stewart IA and Maw M: Mitochondrial mutation associated with nonsyndromic deafness. Am J Otolaryngol 16: 403-408, 1995.

20. Reid FM, Vernham GA and Jacobs HT: A novel mitochondrial point mutation in a maternal pedigree with sensorineural deafness. Hum Mutat 3: 243-247, 1994.

21. Sevior KB, Hatamochi A, Stewart IA, et al: Mitochondrial A 7445G mutation in two pedigrees with palmoplantar keratoderma and deafness. Am J Med Genet 75: 179-185, 1998.

22. Yuan H, Qian Y, Xu Y, et al: Cosegregation of the G7444A mutation in the mitochondrial COI/tRNA ${ }^{\operatorname{Ser}(\mathrm{UCN})}$ genes with the $12 \mathrm{~S}$ rRNA A $1555 \mathrm{G}$ mutation in a Chinese family with aminoglycoside-induced and nonsyndromic hearing loss. Am J Med Genet 138: 133-140, 2005. 
23. Jacobs HT, Hutchin TP, Kappi T, et al: Mitochondrial DNA mutations in patients with postlingual, nonsyndromic hearing impairment. Eur J Hum Genet 13: 26-33, 2005.

24. Schuelke M, Bakker M, Stoltenburg G, Sperner J and von Moers A: Epilepsia partialis continua associated with a homoplasmic mitochondrial tRNA $^{\text {Ser(UCN) }}$ mutation. Ann Neurol 44: 700-704, 1998.

25. Tiranti V, Chariot P, Carella F, et al: Maternally inherited hearing loss, ataxia and myoclonus associated with a novel point mutation in mitochondrial tRNA ${ }^{\operatorname{Ser}(U C N)}$ gene. Hum Mol Genet 4: 1421-1427, 1995.

26. Del Castillo FJ, Villamar M, Moreno-Pelayo MA, et al: Maternally inherited non-syndromic hearing impairment in a Spanish family with the $7510 \mathrm{~T}>\mathrm{C}$ mutation in the mitochondrial tRNA ${ }^{\text {Ser(UCN) }}$ gene. J Med Genet 39: e82, 2002.

27. Hutchin TP, Parker MJ, Young ID, et al: A novel mutation in the mitochondrial tRNA ${ }^{\operatorname{Ser}(\mathrm{UCN})}$ gene in a family with nonsyndromic sensorineural hearing impairment. J Med Genet 37: 692-694, 2000.

28. Li R, Ishikawa K, Deng JH, et al: Maternally inherited nonsyndromic hearing loss is associated with the T7511C mutation in the mitochondrial tRNA ${ }^{\mathrm{Ser}(\mathrm{UCN})}$ gene in a Japanese family. Biochem Biophys Res Commun 328: 32-37, 2005.

29. Sue CM, Tanji K, Hadjigeorgiou G, et al: Maternally inherited hearing loss in a large kindred with a novel T7511C mutation in the mitochondrial DNA tRNA ${ }^{\operatorname{Ser}(\mathrm{UCN})}$ gene. Neurology 52: 1905-1908, 1999.

30. Guan MX, Enriquez JA, Fischel-Ghodsian N, et al: The deafness-associated mitochondrial DNA mutation at position 7445 , which affects tRNA ${ }^{\mathrm{Ser}(\mathrm{UCN})}$ precursor processing, has long-range effects on NADH dehydrogenase subunit ND6 gene expression. Mol Cell Biol 18: 5868-5879, 1998.

31. Del Castillo FJ, Rodriguez-Ballesteros M, Martin Y, et al: Heteroplasmy for the $1555 \mathrm{~A}>\mathrm{G}$ mutation in the mitochondrial $12 \mathrm{~S}$ rRNA gene in six Spanish families with non-syndromic hearing loss. J Med Genet 40: 632-636, 2003.

32. Tarnopolsky MA, Maguire J, Myint T, Applegarth D and Robinson BH: Clinical, physiological, and histological features in a kindred with the T3271C melas mutation. Muscle Nerve 21: 25-33, 1998.

33. Santorelli FM, Mak SC, El-Schahawi M, et al: Maternally inherited cardiomyopathy and hearing loss associated with a novel mutation in the mitochondrial tRNA(Lys) gene (G8363A). Am J Hum Genet 58: 933-939, 1996.

34. Anderson S, Bankier AT, Barrell BG, et al: Sequence and organization of the human mitochondrial genome. Nature 290: 457-465, 1981.

35. Del Castillo I, Villamar M, Moreno-Pelayo MA, et al: A deletion involving the connexin 30 gene in nonsyndromic hearing impairment. N Engl J Med 346: 243-249, 2002.

36. Hofacker IL: Vienna RNA secondary structure server. Nucleic Acids Res 31: 3429-3431, 2003

37. Bibb MJ, Van Etten RA, Wright CT, Walberg MW and Clayton DA: Sequence and gene organization of mouse mitochondrial DNA. Cell 26: 167-180, 1981.

38. Roe BA, Ma DP, Wilson RK and Wong JF: The complete nucleotide sequence of the Xenopus laevis mitochondrial genome. J Biol Chem 260: 9759-9774, 1985.

39. Gadaleta G, Pepe G, De Candia G, Quagliariello C, Sbisa E and Saccone C: The complete nucleotide sequence of the Rattus norvegicus mitochondrial genome: cryptic signals revealed by comparative analysis between vertebrates. J Mol Evol 28: 497-516, 1989.

40. Li Z, Li R, Chen J, et al: Mutational analysis of the mitochondrial $12 \mathrm{~S}$ rRNA gene in Chinese pediatric subjects with aminoglycoside-induced and non-syndromic hearing loss. Hum Genet 117: 9-15, 2005.

41. Abe S, Kelley PM, Kimberling WJ and Usami SI: Connexin 26 gene $(G J B 2)$ mutation modulates the severity of hearing loss associated with the $1555 \mathrm{~A} \rightarrow \mathrm{G}$ mitochondrial mutation. Am J Med Genet 103: 334-338, 2001.

42. Guan MX, Fischel-Ghodsian N and Attardi G: Nuclear background determines biochemical phenotype in the deafnessassociated mitochondrial 12S rRNA mutation. Hum Mol Genet 10: 573-580, 2001.

43. Casano RA, Bykhovskaya Y, Johnson DF, et al: Hearing loss due to the mitochondrial A1555G mutation in Italian families. Am J Med Genet 79: 388-391, 1998.

44. Mkaouar-Rebai E, Tlili A, Masmoudi S, et al: Mutational analysis of the mitochondrial $12 \mathrm{~S}$ rRNA and tRNA ${ }^{\mathrm{Ser}(\mathrm{UCN})}$ genes in Tunisian patients with nonsyndromic hearing loss. Biochem Biophys Res Commun 340: 1251-1258, 2006.
45. Li R, Greinwald JH Jr, Yang L, Choo DI, Wenstrup RJ and Guan MX: Molecular analysis of the mitochondrial 12S rRNA and tRNA $\operatorname{Ser(UCN)}$ genes in paediatric subjects with nonsyndromic hearing loss. J Med Genet 41: 615-620, 2004.

46. Bravo O, Ballana E and Estivill X: Cochlear alterations in deaf and unaffected subjects carrying the deafness-associated A $1555 \mathrm{G}$ mutation in the mitochondrial 12S rRNA gene. Biochem Biophys Res Commun 344: 511-516, 2006.

47. Tekin M, Duman T, Bogoclu G, et al: Frequency of mtDNA $\mathrm{A} 1555 \mathrm{G}$ and $\mathrm{A} 7445 \mathrm{G}$ mutations among children with prelingual deafness in Turkey. Eur J Pediatr 162: 154-158, 2003.

48. Kupka S, Toth T, Wrobel M, et al: Mutation A1555G in the $12 \mathrm{~S}$ rRNA gene and its epidemiological importance in German, Hungarian, and Polish patients. Hum Mutat 19: 308-309, 2002 .

49. Usami S, Abe S, Akita J, et al: Prevalence of mitochondrial gene mutations among hearing impaired patients. J Med Genet 37: 38-40, 2000

50. Malik S, Sudoyo H, Sasmono T, et al: Nonsyndromic sensorineural deafness associated with the A1555G mutation in the mitochondrial small subunit ribosomal RNA in a Balinese family. J Hum Genet 48: 119-124, 2003.

51. Jeong HS, Lim MJ, Chang SO, Kim CS and Oh SH: The frequency of mitochondrial gene point mutations in Korean non-syndromic sensorineural hearing loss. Korean J Otolaryngol 47: 206-211, 2004.

52. Bykhovskaya Y, Estivill X, Taylor K, et al: Candidate locus for a nuclear modifier gene for maternally inherited deafness. Am J Hum Genet 66: 1905-1910, 2000.

53. Bykhovskaya Y, Yang H, Taylor K, et al: Modifier locus for mitochondrial DNA disease: linkage and linkage disequilibrium mapping of a nuclear modifier gene for maternally inherited deafness. Genet Med 3: 177-180, 2001.

54. Bykhovskaya Y, Shohat M, Ehrenman K, et al: Evidence for complex nuclear inheritance in a pedigree with nonsyndromic deafness due to a homoplasmic mitochondrial mutation. Am J Med Genet 77: 421-426, 1998.

55. Guan MX, Fischel-Ghodsian N and Attardi G: A biochemical basis for the inherited susceptibility to aminoglycoside ototoxicity. Hum Mol Genet 9: 1787-1793, 2000.

56. Bacino C, Prezant TR, Bu X, Fournier P and Fischel-Ghodsian N: Susceptibility mutations in the mitochondrial small ribosomal RNA gene in aminoglycoside induced deafness. Pharmacogenetics 5: 165-172, 1995.

57. Yoshida M, Shintani T, Hirao M, Himi T, Yamaguchi A and Kikuchi K: Aminoglycoside-induced hearing loss in a patient with the 961 mutation in mitochondrial DNA. ORL J Otorhinolaryngol Relat Spec 64: 219-222, 2002.

58. Kobayashi K, Oguchi T, Asamura K, et al: Genetic features, clinical phenotypes, and prevalence of sensorineural hearing loss associated with the 961delT mitochondrial mutation. Auris Nasus Larynx 32: 119-124, 2005.

59. Tanaka M, Cabrera VM, Gonzalez AM, et al: Mitochondrial genome variation in eastern Asia and the peopling of Japan. Genome Res 14: 1832-1850, 2004.

60. Kong QP, Yao YG, Sun C, et al: Phylogeographic analysis of mitochondrial DNA haplogroup F2 in China reveals T12338C in the initiation codon of the ND5 gene not to be pathogenic. J Hum Genet 49: 414-423, 2004.

61. Yao YG, Salas A, Bravi CM and Bandelt HJ: A reappraisal of complete mtDNA variation in East Asian families with hearing impairment. Hum Genet 119: 505-515, 2006.

62. Kelsell DP, Dunlop J, Stevens HP, et al: Connexin 26 mutations in hereditary non-syndromic sensorineural deafness. Nature 387: 80-83, 1997.

63. Lerer I, Sagi M, Ben-Neriah Z, Wang T, Levi H and Abeliovich D: A deletion mutation in $G J B 6$ cooperating with a $G J B 2$ mutation in trans in non-syndromic deafness: A novel founder mutation in Ashkenazi Jews. Hum Mutat 18: 460, 2001.

64. Pallares-Ruiz N, Blanchet P, Mondain M, Claustres M and Roux AF: A large deletion including most of GJB6 in recessive non syndromic deafness: a digenic effect? Eur J Hum Genet 10: 72-76, 2002.

65. Del Castillo I, Moreno-Pelayo MA, Del Castillo FJ, et al: Prevalence and evolutionary origins of the del(GJB6-D13S1830) mutation in the DFNB1 locus in hearing-impaired subjects: a multicenter study. Am J Hum Genet 73: 1452-1458, 2003. 